\title{
Erratum: A Spectrum of Selves Reinforced in Multilevel Coherence: A Contextual Behavioural Response to the Challenges of Psychedelic-Assisted Therapy Development
}

\section{OPEN ACCESS}

Approved by:

Frontiers Editorial Office,

Frontiers Media SA, Switzerland

*Correspondence:

Frontiers Production Office

production.office@frontiersin.org

Specialty section:

This article was submitted to

Psychological Therapies,

a section of the journal

Frontiers in Psychiatry

Received: 10 December 2021 Accepted: 10 December 2021

Published: 24 December 2021

Citation:

Frontiers Production Office (2021)

Erratum: A Spectrum of Selves Reinforced in Multilevel Coherence: A Contextual Behavioural Response to the Challenges of

Psychedelic-Assisted Therapy Development.

Front. Psychiatry 12:832766. doi: 10.3389/fpsyt.2021.832766
Frontiers Production Office*

Frontiers Media SA, Lausanne, Switzerland

Keywords: psilocybin-assisted psychotherapy, acceptance and commitment therapy, psychological flexibility, self-perspective taking, psychedelic, internal family systems, relapse prevention, integration

\section{An Erratum on}

A Spectrum of Selves Reinforced in Multilevel Coherence: A Contextual Behavioural Response to the Challenges of Psychedelic-Assisted Therapy Development

by Whitfield, H. J. (2021). Front. Psychiatry 12:727572. doi: 10.3389/fpsyt.2021.727572

Due to a production error, the word "story" was misspelled in the article. A correction has been made to all instances of "storey" and "storeys" in the article. They have been corrected to "story" and "stories."

Due to a production error, reference citation (1) was incorrectly linked in the Introduction, line 3 and line $\mathbf{5}$. The citation on line $\mathbf{3}$ has now been linked to the corresponding reference, while the citation on line 5 has been un-linked.

The publisher apologizes for these mistakes. The original version of this article has been updated.

Copyright $\odot 2021$ Frontiers Production Office. This is an open-access article distributed under the terms of the Creative Commons Attribution License (CC BY). The use, distribution or reproduction in other forums is permitted, provided the original author $(s)$ and the copyright owner(s) are credited and that the original publication in this journal is cited, in accordance with accepted academic practice. No use, distribution or reproduction is permitted which does not comply with these terms. 